\title{
SEQUENTIAL ANALYSIS OF THE APTIAN DEPOSITS FROM THE SÃO LUÍS AND GRAJAÚ BASINS, MARANHÃO STATE (BRAZIL) AND ITS IMPLICATION FOR UNRAVELING THE ORIGIN OF EVAPORITES.
}

\author{
DILCE DE FATIMA ROSSETTI ${ }^{1}$, JACKSON DOUGLAS PAZ ${ }^{2}$, ANA MARIA GOES ${ }^{2}$ \\ AND MOACIR JOSE BUENANO MACAMBIRA ${ }^{2}$
}

\begin{abstract}
Sequential analysis of Aptian deposits of the São Luís and Grajaú Basins using gamma-ray logs resulted in the recognition of a $2^{\text {nd }}$-order depositional sequence bounded by two regional unconformities and internally characterized by a tripartite subdivision attributed to lowstand (LST), transgressive (TST) and highstand (HST) systems tracts. The LSI consists of two parts, a marine and a non-marineinfluenced one, respectively located northward and southward of the Ferrer-Urbano Santos Arch. The TST consists of transgressive marine mudstones that cover the LST. The HST consists of aggressing, marine-influenced deposits that grade upward and southward into fluvial and deltaic strata. More than one episode of evaporite deposition is recorded in this sequence, with the most extensive beds confined to the nonmarine portion of the LST. This, together with sedimentological, paleontological and strontium isotope data, suggest continental-brines as the most likely source for the evaporites of the São Luís and Grajaú Basins. Less extensive evaporite minerals associated with shallow marine deposits formed at the transition from the TST to HST, and are probably derived from marine brines.
\end{abstract}

Keywords: lacustrine setting, evaporites, sedimentology, sequence stratigraphy, strontium isotope

INTRODUCTION Evaporite deposits are widespread throughout the Brazilian Marginal Basins, with the southernmost areas bearing the thickest successions. One of the fundamental questions concerning to these deposits is whether they formed from evaporite-precipitating sea water brines or from non-marine sources. Several studies have been undertaken in order to determine the age and paleoenvironmental setting of the Cretaceous Brazilian evaporites. A marine influence has been more often proposed to explain the evaporitic phases of several of the southernmost marginal basins (e.g., Silva-Telles Jr. 1996, Araujo et al. 1998, Dias 1999). On the other hand, a more continental genesis has been proposed for the evaporites formed in the northeastern and northern Brazilian basins. For instance, evaporite deposits from the Sergipe-Alagoas (Paripueira/Ibura), Ceara (Trairi Beds), and Araripe (Ipubi Members) Basins formed during the EoAptian and Neo-Aptian in a lacustrine environment (Hashimoto et al. 1987, Uesugui 1987). The marine evaporites of these basins formed only at the end of the Neo-Aptian (i.e., palynomorph zone P270-2 and P280-1; Regali and Silva Santos 1999).

Evaporite beds are well known from the São Luís and Grajaú Basins formed during the early stages of the South Atlantic rifting. The evaporite deposits occur in the Aptian Codó Formation. Few studies attempt to provide an interpretation on the origin of these deposits. A marine brine has been proposed (e.g., Rodrigues 1995). The purpose of this paper is to present a sequential stratigraphic model for the evaporite-bearing deposits of the São Luís and Grajaú Basins in order to provide a basis for discussing their genesis, as well as to show that there were more than one episode of evaporite formation. Our data will show that, while evaporite deposits from northernmost areas (i.e., São Luís Basin) are associated with marine-influenced strata, the evaporite beds from the southeastern and eastern margin of the Grajaú Basin were preferentially formed in a closed, lacustrine environment.

STRATAL ARCHITECTURE The evaporite deposits of the São Luís and Grajaú Basins form intervals are up to $18 \mathrm{~m}$ thick. They occur at variable (i.e., 420 to $1630 \mathrm{~m}$ ) depths in the São Luís and central parts of the Grajaú Basins, while at the basin margins are few meters below the surface, as recorded by numerous cores and open mining exposures near the Codó area, eastern Maranhão State (Fig. 1). Analysis of gamma-ray logs of sequence stratigraphy has allowed correlating both the evaporite beds and evaporite-bearing deposits. This is the first step to understand the origin of these evaporites, particularly considering their episodic nature, as follows..

The evaporite-bearing succession Detailed correlation of 11 well $\operatorname{logs}$ along a north-south transect through the São Luís and Grajaú Basins (Fig. 1), respectively, led to the recognition that the evaporite deposits are confined to a thick (i.e., up to $500 \mathrm{~m}$ ) sedimentary succession attributed to a mega-depositional sequence of the lower portions of these basins. This succession is defined by two discontinuity surfaces. The basal one is easily traced throughout the transect (i.e., a distance up to $500 \mathrm{Km}$ ), being most commonly marked by a subtle increase in gamma-ray signals, indicating a sharp lithological boundary with the underlying Paleozoic deposits of the Parnafba Basin or crystalline basement. The upper surface is also marked in all wells by a subtle increase in the gamma-ray pattern, indicating a sharp, erosive contact with the overlying deposits.

The succession bounded by the two discontinuity surfaces defined above was deposited during the Late Aptian to Early Albian (corresponding to the palynomorph zones P270-P280). These deposits form a wedge-shaped interval that progressively onlaps the margins of the Grajaú Basin to the south. Three units are internally recognized within the succession, which are herein informally referred to as Unit 1 to 3 to help descriptions (Fig. 2).

Unit 1 This unit directly overlies the basal discontinuity surface, and can be subdivided into two parts. The deposits located in the Grajaú Basin, southward of the Ferrer-Urbano Santos Arch, is a $180 \mathrm{~m}$ thick-unit consisting of sandstones, shales (including black, bituminous shale), and minor carbonates, and evaporites. The lowermost $100 \mathrm{~m}$ of this interval consists of sandstones displaying high gamma ray that progressively decreases upward, forming an overall bell-shaped curve. These deposits display a lenticular geometry at the southernmost margin of the Grajaú Basin. The remaining uppermost deposits include two intervals (up to $25 \mathrm{~m}$ thick each) of shales (low gamma ray) topped by sandstone and/or evaporite beds (high gamma ray), which result in funnel-shaped patterns. Marine fauna has not been recovered from these deposits, except for rare reworked fragments of echinoderms (well 1-CI-IMA; Batista 1992). The continuity of Unit 1 in the São Luís Basin is represented by a wedge-shaped package up to $150 \mathrm{~m}$ thick interfingered with the stratigraphically correlatable deposits of the Grajaú Basin in the proximity of the Ferrer-Urbano Santos Arch (2-CG-1-MA). Conversely to the muddy nature in the Grajaú Basin, the bulk of Unit 1 in the São Luís Basin consists of sandstones with a blocky-to bellshaped gamma-ray pattern. Carbonate and mudstone beds occur locally interfingered with the sandstones. A marine influence during deposition of this succession is indicated by the presence of dinoflagellates and foraminifers (e.g., wells 2-AL-1-MA, 1-CG-3-MA, 2-CG-l-MA). Evaporite deposits are absent from this interval, except for traces of anhydrite recorded in the well 1 -AL-1-MA.

Unit 2 This unit consists of a muddy interval up to $50 \mathrm{~m}$ thick, which sharply drapes the underlying Unit 1 throughout the entire extension of the São Luís and Grajaú Basins, forming a wedge-shaped package that pinches out southward. This stratigraphic interval contains a rich marine fauna including bryozoans, foraminifers, pelecypodes and ostracodes (i.e., well 1-PE-l-MA). In addition, dinoflagellates are common throughout both basins (e.g., wells 2-AL1-MA, 1-PE-1-MA, 2-CG-1-M, 1-IV-1-MA, 1-RL-1-MA).

Unit 3 This unit overlies the marine fossil-rich deposits of Unit 2, extending throughout the São Luís and Grajaú Basins. It forms a thick 


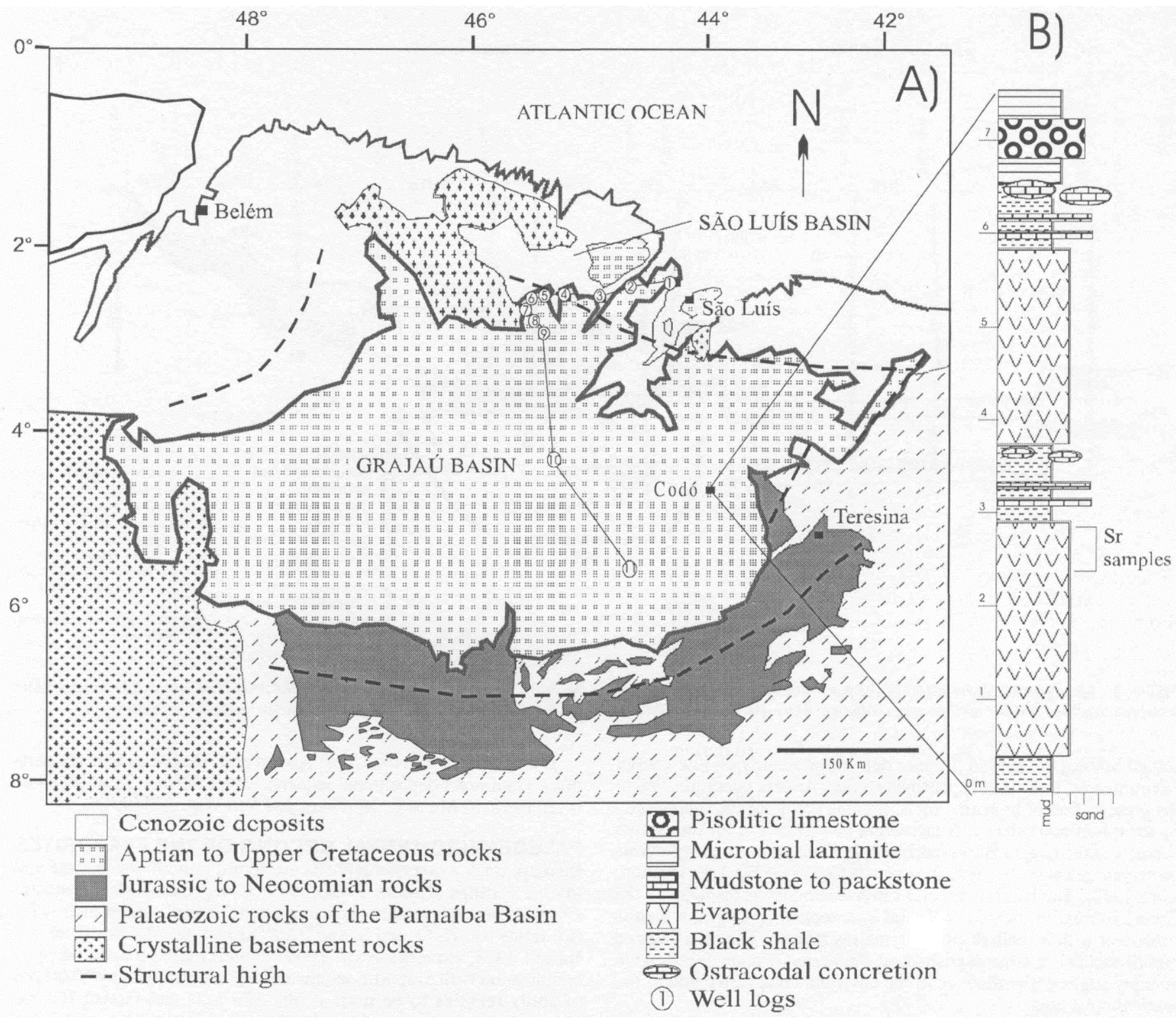

Figure 1-A) Location map of the São Luís and Grajaú Basins in the Maranhão State, Brazil. The transect north-south indicate the position of the studied wells, where: 1=1-AL-1-MA; 2=1-BO-1-MA; 3=1-PE-1-MA; 4=1-CG-3-MA; 5=1-CG-J-MA; 6=1-IV-1-MA; 7= 1-RL-1-MA; 8=1-AT-1-MA; 9=1-CI-1-MA; 10=1SL-l-MA; 11=1-PD-1-MA. B) A vertical profile near the town of Codó, where the evaporite deposits are exposed, with indication of the samples collected for the strontium analysis discussed in this paper.

interval (nearly $300 \mathrm{~m}$ thick) consisting of sandstones and mudstones locally interbedded with carbonates and evaporites. The two latter, as well as dinoflagellates are confined to the São Luís Basin (i.e., wells 2AL-1-MA, 1-BO-1-MA, 1-PE-1-MA, and wells 2-AL-1-MA, 1-PE-1MA, respectively). The thickness of Unit 3 decreases southward as it pinches out against the margins of the Grajaú Basin. In the northernmost areas, the lowermost deposits (circa $200 \mathrm{~m}$ thick) are internally organized into well-developed aggrading stacking patterns, indicated by nearly constant gamma-ray values. These gamma ray pattern changes upward and southward, configuring either bell-shapes or funnel-shape, or even a bell-shape that grades upward into a funnelshape. These deposits include interbedded sandstones and mudstones formed under dominant continental conditions as suggested by the absence of any marine fauna. The evaporites recorded in Unit 3 form two discontinuous stratigraphic levels (well 1-BO-1-MA) located near the transition from packages displaying aggrading to bell-shaped patterns. The top of Unit 3 is a regionally correctable discontinuity surface recognized by a subtle change in gamma-ray pattern from low to high values, which is attributed to a period of drastic lithological change throughout the São Luís and Grajaú Basins. THE SEQUENCE STRATIGRAPHIC MODEL The strata architecture described above matches the concept of a depositional sequence, defined by two unconformities (i.e., the basal discontinuity surface with the crystalline basement or Paleozoic deposits of the Parnaiba Basin and the upper discontinuity surface at the top of Unit 3 ) and a tripartite subdivision representing the lowstand (LST), transgressive (TST) and highstand (HST) systems tract. Hence, Unit 1 is proposed to record the LST preserved right above the basal sequence boundary. The northern portion of this unit was deposited in a marineinfluenced environment, as suggested by the frequent occurrence of dinoflagellates and foraminifers (Fig. 2). Despite the local occurrence of equinoderms in well 1-CI-1-MA (Batista 1992), the marine influence appears to decrease progressively southward in this unit. This is partly suggested by the absence of any other marine fauna. In addition, surface data from eastern Grajaú Basin support a strong continental influence, suggested by the presence of widespread freshwater ostracodes and Charophyta (Paulo Milhomem personal communication). Marine-influenced trace fossils, expected to be widespread during transgressions, have not been reported in these deposits. Nor have transgressive lags been recorded as an indication of either tide or wave reworking along the shoreline area. In fact, fades architecture shows prograding, rather than, transgressive stacking patterns within these deposits ( $\mathrm{Paz}$ and Rossetti 1999). These evidences, associated with the dominance of fine-grained, suspension- 
São Luís Basin $\quad$ Grajaú Basin

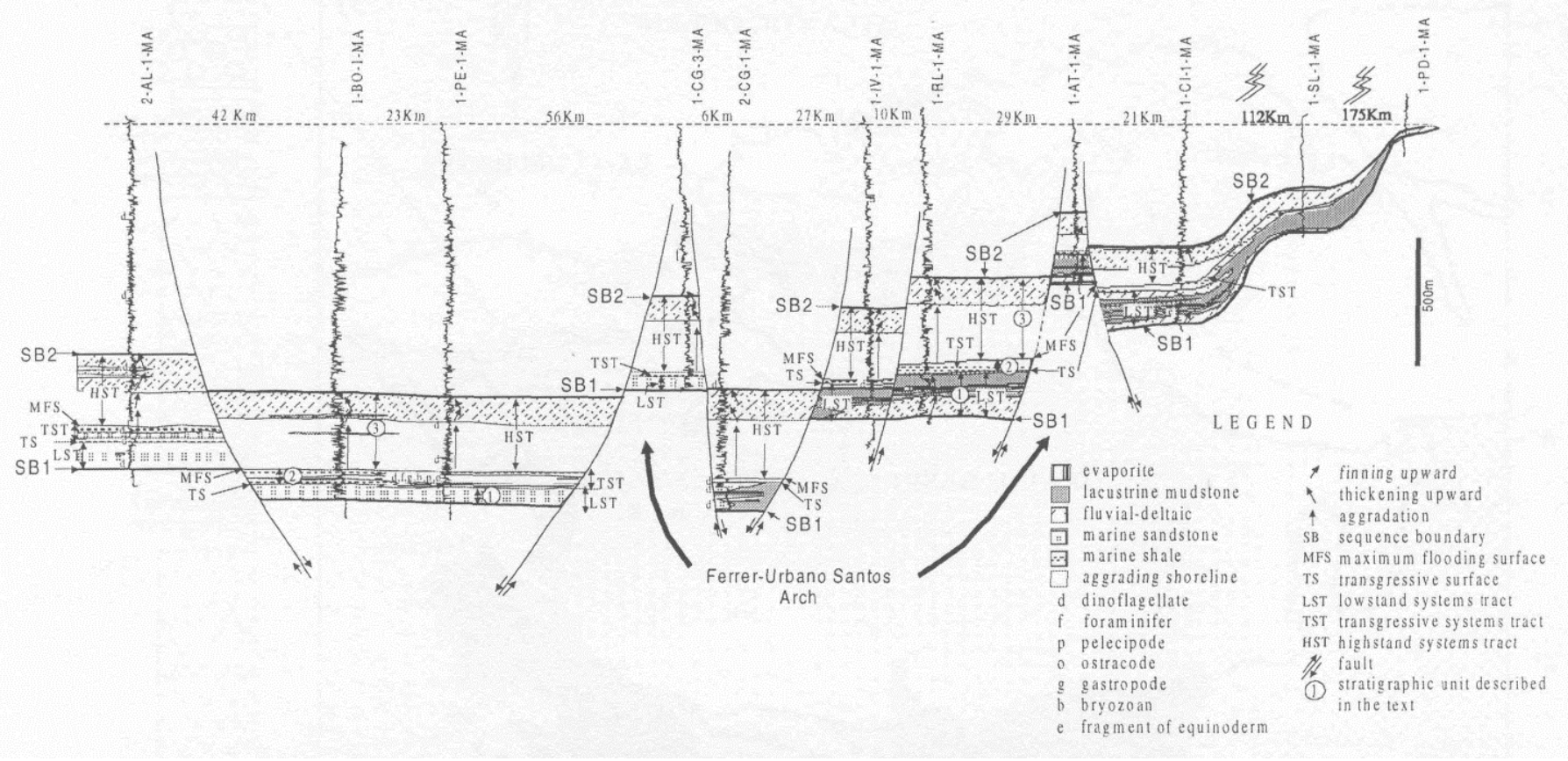

Figure. 2 - Stratigraphic correlation of the Aptian-Albian deposits throughout the São Luís and Grajaú Basins, with the proposed sequential stratigraphic interpretation (see text for further explanations). Wells are represented by gamma ray logs, except 1-PD-1-MA, which is spontaneous potential.

settled lithologies, lead to propose deposition mainly on low-energy environments, typical of lacustrine settings. Anoxic conditions led to the preservation of high amount of organic components, represented by the bituminous shales. A lacustrine interpretation for the Aptian deposits in the Grajaú Basin has been previously proposed with basis on palynological studies near the town of Codó (see Fig.l for location; Lima 1982). The basal, lenticular sandstone body corresponds to the Grajaú Formation, which is fluvial and aeolian in origin, which is consistent with its bell-shaped gamma-ray pattern. The interfingered marine and non-marine deposits near the Ferrer-Urbano Santos Arch strongly suggest its influence in the environmental restriction of the southernmost area.

Unit 2 records a period when the marine influence reached the most inland areas, resulting a mantle of marine mudstones overlying Unit 1 throughout the whole extension of the São Luís and Grajaú Basins. These characteristics, together with the intermediate position in the sequence directly overlying the LST, led to attribute Unit 2 to the TST. The presence of fossil rich-marine shales in this interval record periods of low sediment influx to the basin, which is consistent with transgressions. The boundary between Unit 2 and the underlying Unit 1 records the first full marine conditions in the Grajaú Basin, and thus it is a good candidate for a transgressive surface. It is noteworthy to mention that transgression is a diachronous event that might include several small-scale, backstepping pulses, which are not possible to be identified in this study. The rare equinoderm fragments documented in the southernmost portion of Unit 1 (i.e., well 1-CI-1-MA), if not reworked, might be a record of one of these transgressive pulses.

The $300 \mathrm{~m}$ thick uppermost deposits (i.e., Unit 3) were formed in a HST, an interpretation based on: i) the position overlying the TST; and ii) the aggrading strata stacking patterns, typical of this HST. The belland funnel-shaped gamma-ray patterns developed at the top of this unit, as well as southward, probably formed when sea level began to fall at the end of the HST. This is the time for progradation of the alluvial system, with development of mouth bar, distributary and fluvial channels, which in the study area might be correlated with the funnel and bell shaped gamma-ray patterns, respectively. The lack of marine fauna in these uppermost and landward deposits is consistent with a progressively more terrestrial influence during the last stages of development of this depositional sequence. The time for maximum marine flooding occurred right below Unit 3, at the top of the marine shales (i.e., Unit 2), just before the highstand aggradation.
It is suggested that the Upper Aptian units described here are parts of a second-order depositional sequence, since the time range involved is around 8-10 Ma (e.g., Mitchum and Van Wagoner 1991).

\section{PALEOENVIROMENTAL SETTING OF THE EVAPORITES}

Because thick evaporite deposits are found in both non-marine and marine settings (Hardie 1984), deciphering the origin of ancient evaporite minerals requires systematic geochemical studies such as $\mathrm{Br}^{-}$ $/ \mathrm{Cl}^{-}$ratios and $\mathrm{H}, \mathrm{O}$, and $\mathrm{S}$, and ${ }^{87} \mathrm{Sr}{ }^{80} \mathrm{Sr}$ isotope rations (Faure and Barrett 1973, Hovorka et al. 1993), which must be undertaken in combination with evaporite sedimentology and stratigraphy. This type of study remains to be done in the São Luís and Grajaú Basins. However, considering the foregoing sequence stratigraphic model, it is appropriated to introduce a preliminary discussion on the genesis of these evaporite deposits, which might be useful to drive future studies on this issue. There are more than one evaporite-bearing interval in the São Luís and Grajaú Basins, with the two most extensive ones being confined to the more continental-influenced part of the LST. Due to the interfingering between marine and non-marine deposits at certain point in this systems tract, one interpretation is that the evaporiteprecipitating brines evolved from seawater flooded into the restricted lake domain during lowstand. This hypothesis might explain part, but not all, of the evaporites occurring in the Grajaú Basin. Ongoing studies focusing evaporite-bearing exposures in the eastern portion of this basin favor continental, rather than marine brines during the evaporite deposition. The sedimentological data from the Codó area, as discussed in the foregoing chapter, strongly suggest a lacustrine setting for the evaporites. Detailed fades analysis has shown that the evaporite deposits are confined to central lake deposits that occur at the base of shoaling upward cycles (Paz and Rossetti 1999) formed during the lowstand lake progradation. If any marine incursion took place in this setting, then it would cause transgressive, rather than, regressive fades pattern. In addition, if the evaporites precipitated from the marinebrine during transgression, then the marginal lake deposits at the top of the shoaling upward cycles would bear pervasive evaporite minerals, which is not the case in the Codó area.

In order to test the non-marine hypothesis for the evaporite deposits of the Grajaú Basin, we conducted a preliminary measurement of ${ }^{87} \mathrm{Sr} /$ ${ }^{86} \mathrm{Sr}$ ratio using anhydrite minerals from three samples collected in the Codó area (see Fig 1 for location). Analysis of ${ }^{87} \mathrm{Sr} /{ }^{86} \mathrm{Sr}$ have been particularly used to characterize marine and continental evaporites and 
carbonates, if a $\mathrm{Rb} / \mathrm{Sr}$ ratio of less than 0.1 is observed (e.g., Clauer 1976, Faure and Barrett 1973), as reported in the study area. This methodology takes into account that the distribution of strontium in marine evaporites changed in a systematic fashion throughout the Phanerozoic. Disregarding other influences (e.g., diagenesis), a nonmarine indication is suggested when the strontium composition does not match with the pre-established strontium curve for marine carbonates and evaporites (e.g., Burke 1982).

We sampled representative anhydrite nodules to conduct this test because, according to petrographic criteria, they represent the earliest evaporite minerals recorded in the Codó area, which increased the possibility for a depositional signature. The results indicated ${ }^{87} \mathrm{Sr}{ }^{86} \mathrm{Sr}$ average ratio of 0.7079 (Table 1). The strontium isotopic composition of Aptian marine seawater averaged 0.7072-0.7073 (Burke et al. 1982). By comparing these values with our strontium isotope data, we found that our results were 0.0006-0.0007 higher than the marine value for that period (Fig. 3) which, considering the overall depositional setting proposed herein, suggest freshwater brines.

Table $1-{ }^{87} \mathrm{Sr}^{86} \mathrm{Sr}$ ratio from the Codó area.

\begin{tabular}{|c|c|c|}
\hline Sample & ${ }^{87} \mathrm{Sr} /{ }^{86} \mathrm{Sr}$ & Standard Deviation \\
\hline 1 & 0.707960 & 0.000034 \\
2 & 0.707989 & 0.000023 \\
3 & 0.707824 & 0.000046 \\
\hline
\end{tabular}

Previous geochemical studies from the well 1-CI-1-MA. located nearly $150 \mathrm{Km}$ northwest of the Codó area, pointed to ${ }^{87} \mathrm{Sr} /{ }^{86} \mathrm{Sr}$ ratios of $0.7080-0.7088$ for the evaporite beds, which are claimed to have a marine origin (Rodrigues 1995). These strontium values are much higher than the ones expected for marine Aptian evaporites, which was justified by that author as due to a freshwater influx. Our sequential model could easily accommodate the marine influence in the well 1CI-l-MA, as discussed in the previous section. However, a significant amount of dilution by freshwater is needed to alter the $\mathrm{Sr} / \mathrm{Sr}$ ratio of marine waters (Reinhardt et al. 1998). In addition, the strontium values from the well 1-CI-1-MA are similar to the ones obtained in the Codó area, attributed in this study to freshwater brine. These are somewhat conflicting interpretations, and must be taken into account in future studies dealing with this issue. A freshwater interpretation for the evaporite beds in the Codó area is the hypothesis preferred herein taking into account: $i$. the sedimentological and paleontological evidences supporting a lacustrine setting for the shales and limestones interbedded with the evaporites; and ii. the strontium ratio considerably above the curve of seawater for the Aptian period. Noteworthy to mention that a degree of variability from the curve of seawater ${ }^{87} \mathrm{Sr} /{ }^{86} \mathrm{Sr}$ ratio similar to the one obtained in the study area has been used to suggest a non-marine water source for ${ }^{87} \mathrm{Sr}$ in many other ancient deposits (e.g., Faure and Barrett 1973, Clauer 1976, Hovorka at al. 1993, Schmitz et al. 1997, Reinhardt et al. 1998).

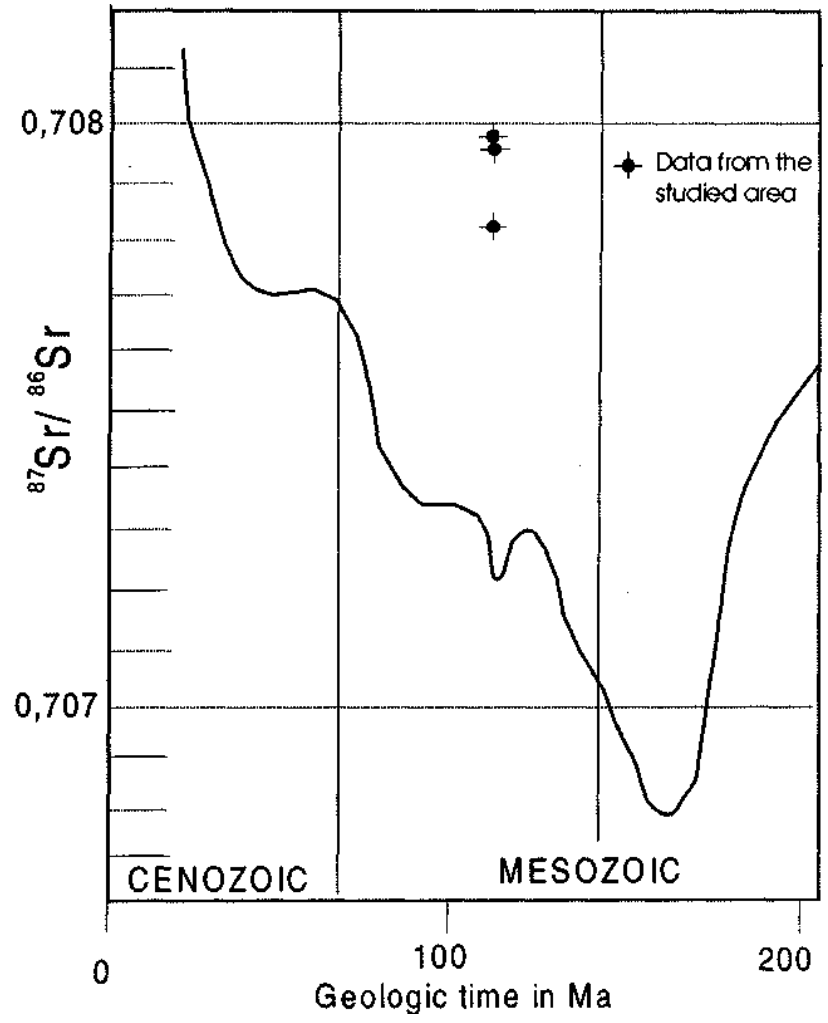

Figure 3 - Curve ofSr isotopic variation of marine deposits through time, with the plot of data collected from the study area.

Evaporite-bearing intervals also occur in the HST, but in this case they are much less continuous laterally. According to the proposed sequence stratigraphic model, these deposits formed in a marine setting at the highstand stages right when sea level started to slowly decline. Under this condition, marginal sabkhas were likely to form in association with the shoreline progradation favoring precipitation of evaporite minerals. Future studies should consider the analysis of strontium composition of these evaporite beds in order to compare with the values obtained in the Codó area.

Acknowledgments This paper was supported by a grant from the CNPq (project 400039/99-0). To the Goeldi Museum and Universidade Federal do Para for the logistical support, Cintia M.G. da Silva for helping with the laboratory work and to two anonymous referees of $\mathrm{RBg}$ for the critical analysis of the manuscript.

\section{References}

Araújo C.V., Conde V.C., Botelho-Neto J., Pedrão E., Conceição J.C.J. 1998. Palynofacies in a sequence stratigraphy context, an example of an upper Aptian section from Almada Basin, Brazil. In: AAPG International Conference and Exhibition, 82:18861887 (Abstract Book)

Batista A.M.N. 1992. Caracterização Paleoambiental dos sedimentos Codó-Grajaú, Bacia de São Lui's (MA). Belem, 102 pp. (Tese de Mestrado, UFPA)

Burke W.H., Denison R.E., Hetherington E.A., Koepnick R.B., Nelson, H.F., Otto J.B. 1982. Variation of seawater ${ }^{87} \mathrm{Sr}{ }^{8} \mathrm{Sr}$ throughout Phanerozoic time. Geology, 10:516519

Clauer N. $1986 .{ }^{87} \mathrm{Sr} /{ }^{86} \mathrm{Sr}$ composition of evaporitic carbonates and sulphates from Miocene sedime

Dias J.L. 1999. O andar Aptiano na margem leste do Brasil e as primeiras incursões e ingressões marinhas no Oceano AtTantico sul meridional. In: V Simp. Cretáceo no Brasil/Simp. Sobre el Cretácico de America del Sur, Serra Negra, p. 3-9 (Resumo Brasil/Simp.

Faure G. \&. BARRETT P.J. 1973. Strontium isotope composition of non-marine carbonate rocks from the Beacon Supergroup of the Transantarctic Mountains. Journal of Sed. Petr., 43: 447-457.

Hardie L.A. 1984. Evaporites: Marine or non-marine?: Am. Jour. Sci., 87:193-240.

Hardie L.A. 1984. Evaporites: Marine or non-marine?: Am. Jour. Sci., 87:193-240. do Ceará, Araripe e Potiguar (Brasil): caracterização estratigráfica e paleoambinetal. do Ceará, Araripe e Potiguar (Brasil):

Hovorka S.D., Knauth L.P., Fisher R.S., Gao G. 1993. Marine to nonmarine facies transition in Permian evaporites of the Palo Duro basin, Texas: geochemical response. Geol. in Permian evaporites of the Pa

Lima M.R. 1982. Palinologia da Formação Codó, Maranhão. Boletim do Institute) de Geociências-USP 13:116-128.

Mitchum R.M.JR. \& Van Wagoner J.C. 1991. High-frequency sequences and their stacking patterns: sequence-stratigraphic evidence of high-frequency eustatic cycles. In Biddle K.T. \& Schlager W., eds., The Record of Sea-Level Fluctuations. Sedimentary Geology, 70:131 -160.
Paz J. D. \& Rossetti D.F. 1999. Analise faciologica da Formação Codó (Aptiano Superior) na regiao de Codó (Ma), leste da Bacia do Grajaii. In: V Simp. Cetáceo no Brasil// 1 Simp. Sobre el Cretácico de America del Sur, Serra Negra, p. 201-207 (Resumo expandido)

Regali M.S.P. \& Silva Santos P.R., 1999. Palinoestratigrafia e geocronologia dos sedimentos Albo-Aptianos das bacias de Sergipe e de Alagoas-Brasil. In: 5 Simpósio Sobre o Cretáceo no Brasil, Serra Negra, p 411-419 (Abstract Book)

Reinhardt E.G., Stanley D.J., Patterson R.T. 1998. Strontium isotopic-paleontological methods as a high-resolution paleosalinity tool for lagoonal environments. Geology, 26:1003-1006.

Rodrigues R. 1995. A geoquímica Orgânica na Bacia do Parnaiba. Porto Alegre, 225 pp. (Tese de Doutorado, UFRGS)

Schmitz B., Ingram S.L., Dockery III D.T., Aberg G. 1997. Testing ${ }^{87} \mathrm{Sr} r{ }^{86} \mathrm{Sr}$ as a paleosalinity indicator on mixed marine, brackish-water and terrestrial vertebrate skeletal apatite in late Paleocene-early Eocene near-coastal sediments, Mississippi. Chemical Geology, 140:275-287.

Silva-Telles Jr. A.G. 1996. Estratigrafia de Sequências de Alta Resolução do Membro Coqueiros da Formação Lagoa Feia (Barremiano?/Aptiano da Bacia de CamposBrasil) Porto Alegre, 2v., 268 pp. (Dissertação de Mestrado, UFRGS).

Summons R.E. \& Powell T.G. 1987. Identification of aryl isoprenoids in source rocks and crude oils: biological markers for the green sulphur bacteria. Geochim. Cosmochim. Acta, 51:557-566.

Summons R.E., Volkman J.K., Boreham C.J. 1987. Dinosterane and other steroidal hydrocarbons of dinoflaggellate origin in sediments and petroleum. Geochim. Cosmochim. Acta, 51:3075-3082

Uesugui N. 1987. Posicão estratigráfica dos evaporitos da Bacia de Sergipe-Alagoas. Revi. Brasil. Geociências, 17:131-134. 